\title{
Peningkatan Perekonomian Masyarakat Pesisir Melalui E-Business di Desa Dapenda Kecamatan Batang-batang
}

\author{
Oleh :
}

\author{
Ahmad Ghufrony ${ }^{1)}$, Liyanto $^{2)}$, Imam Hidayat ${ }^{3)}$ \\ ${ }^{1,2)}$ Fakultas Ekonomi dan Bisnis, Prodi Manajemen, Universitas Wiraraja, ${ }^{3)}$ Fakultas IlmuSosial \\ dan IlmuPolitik, Prodi Administrasi Publik, Universitas Wiraraja \\ E-mail : ghufrony@wiraraja.ac.id ${ }^{1)}$, liyanto@wiraraja.ac.id ${ }^{2) .}$ imamhidayat@wiraraja.ac.id ${ }^{3)}$
}

\begin{abstract}
Abstrak
E-business adalah sebuah aplikasi jual beli yang memudahkan masyarakat pesisir di Dapenda untuk lebih menangkap peluang usaha atau dagangannya ke pangsa pasar yang lebih luas dengan jangkauan informasi tidak terbatas. E-business merupakan dampak positif dari bergeraknya dunia digitalisasi yang semakin tinggi yang memudahkan penggunanya dalam memperoleh keuntungan. Sisi positif dari era digitalisasi ini memberikan ruang kepada masyarakat untuk lebih kretif sehingga kehadirannya memberikan nilai tinggi bagi masyarakat dalam membentu pengahasilan untuk memperbaiki taraf ekonominya. Padahal jika dilihat dari keunggulan Desa Dapenda dengan potensi kekayaan alamnya, hasil ikan laut, ikan laut diolah menjadi terasi, cemara udang, dan kelapa hijau adalah nilai tambah bagi Desa Dependa, maka sangat wajar jika potensi ini merupakan mata pencarian warganya dalam mencukupi kehidupan sehari-harinya. Namun permasalahnnya kehadiran tekhnologi infromasi yang semakin canggih tidak satupun orang memenfaatkan ini sebagai peluang untuk dijadikan sebagai salah satu alat promosi didunia perdardaganya, lemahnya tingkat kesadaran ini tidak memberikan nilai tambah bagi dunia usaha atau perdagangannya. Maka dari itu perlu adanya trobosan baru yang berani menggunakan cara baru dengan penggunaan yang mudah, melalui proposal ini kami memberikan sentuhan edukasi teknologi yaitu dengan menghadirkan e-business sebagai solusi yang tepat dalam membantu usaha dan perdagannya. E-business menghadirkan edukasi dengan gampang digunakan, praktis dan simple untuk digunakan masyarakat dalam berjualan dimedia sosial dengan jangkaun yang lebih luas dan pangsa pasar yang tidak terbatas.
\end{abstract}

Kata Kunci:Pemanfaatan Tekhnologi, Ekonomi kreatif, E-business

\section{Pendahuluan}

Nampaknya akibat dari
perkembangan era digitalisasi ini
berdampak pada semua sektor
kebutuhan masyarakat, hingga dunia
bisnis pun tidak luput dari dampak era
digitalisasi. Dulu yang biasanya
melakukan kegiatan bisnis tampa
melalui tatap muka dengan si pembeli
dan penjual tidak akan menambah rasa
kepercayaan dalam melakukan transaksi
perdagangan. Namun hari ini kegiatan
jual beli tidak harus bertemu dengan si

pembeli atau si penjual cukup dengan bermodalkan teknologi media sosial proses negoisasi sudah rampung dan keinginanpun terwujud. Kegiatan bisnis harus selalu mampu beradaptasi dengan perubahan lingkungan yang terus menerus. Salah satu faktor yang memicu perubahan tersebut adalah perkembangan teknologi berbasis komputer ditunjang dengan keberadaan internet. (Adi Setiawan 2017)

$$
\text { Kesempatan itu belum }
$$
termanfaatkan secara optimal oleh 
untuk memenuhi kebutuhan sehariharinya.Kawasan pesisir merupakan kawasan yang memiliki sejumlah pemanfaatan (multiple use zone). Beragamnya pemanfaatan di kawasan pesisir banyak dipengaruhi oleh keberadaan sejumlah ekosistem. (Yanuar Nurdiansyah 2017)

Aktifitas berdagang tersebut menjadi keunggulan masyarakat dapenda namun akan bertambah nilai tinggi lagi apabila mampu memnfaatkan peluang tekhnologi sebagai salah satu sarana dalam rangka mempromosikan dagangannya ke daerah yang lebih luas yan pangsa pasar nya pun juga lebih luas.

Penulis mencoba memberikan solusi permasalahan diatas, dengan memberikan pemahaman dan aplikasi berbentuk tekhnologi yang gampang digunakan yaitu "Peningkatan perekonomian masyarakat pesisir melalui e-business (Desa Dapenda Kec. Batang-batang)"

Masyarakat pesisir di Desa Dapenda dengan mata pencariannya sebagian masyarakatnya adalah menjajakan dagangannya tidak mampu menangkap peluang era tekhnologi sehingga pergerakan ekonominya masih lambat.

Menjadi hal penting bagi masyarakat pesisir di Desa Dapenda dengan menggunakan e-business sebagai solusi bagi warga dalam 
memberikan dampak positif bagi

kemajuan ekonominya.

\section{Metode Pelaksanaan}

Metode pelaksanaan prorgram kemitraan ini berupa pelatihan dan pendampingan. Pelatihan akan dilaksanakan di lokasi mitra yaitu Desa Dapenda Kecamatan Batang-batang Kabupaten Sumenep yang berjarak 26 km dari Universitas Wiraraja Sumenep. Pelatihan e-business akan diberikan oleh ketua tim Program Kemitraan Masyarakat dan Anggota 1 memiliki tugas sebagai pengelola lebih detail mengenai cara menjalankan tata teknis sistem aplikasi e-business serta menganalis tindak lanjut usaha dilapangan, sedangkan anggota 2 yang memiliki keahlian dalam ilmu tekhnologi sistem informasi e-business. Peserta dalam pelatihan ini adalah masyarakat desa sebanyak 20 Orang. Pelatihan akan dilaksanakan di lokasi mitra yaitu Desa Dapenda Kecamatan Batang-batang Kabupaten Sumenep.

Kegiatan pelatihan terdiri dari proses penyampaian materi dalam betuk ceramah, diskusi serta praktek menjalankan aplikasi e-business. Melalui tahapan kegiatan ini maka akan tercipta keterampilan baru pada mitra yang mampu memberikan wawasan pengetahuan promosi dimedia sosial yang sebelumya dilakukan dengan mengandalkan tatap muka namun dengan sistem ini masyarakat cukup mempromosikan usahanya melalui smartphone yang cepat dan aman. Selain kegiatan pelatihan tim Program Kemitraan Masyarakat juga akan melakukan pendampingan, pelatihan serta evaluasi agar sistem ini selalu bisa diapakai dimasa yang akan datang. Bentuk pendampingan pelatihan ini berupa kunjungan tim Program Kemitraan Masyarakat ke lokasi mitra untuk mengevaluasi jalannya $e$ business. Kegiatan pelatihan maupun kunjungan untuk evaluasi akan dilaksanakan pada hari sabtu dan minggu.

Dalam pelaksanaan kegiatan program kemitraan masyarakatakan melibatkan 2 mahasiswa, yaitu dari Program Studi Administrasi Publik Universitas Wiraraja. Adapun mahasiswa tersebut, Muhammad Mujib Ary Fadhana (717112629) Prodi Manajemen dan Alfina Meidyanti (717112643) Prodi Administrasi Publik.

\section{Hasil dan Pembahasan}

Dalam rangka mnegetahui kegiatan pengabdian masyarakat ini, tim melakukan evaluasi pengabdian tentang kegiatan yang sedang diselenggarakan, terlebih pelatihan tentang tata promosi dagang melalui media online. Karena aktifitas hari ini sudah dengan cara online terlebih dunia dagang.

Kegiatan usaha ekonomi masyarakat sudah seharusnya merujuk pada pemanfaatakan fasilitas digitalisasi 
dapat dimanfaatkan dengan positif, hadirnya pengabdian ini memberi stimulus bagi pelaku bisnis yang awalnya mengandalkan promosi dan jual beli barang dilakukan melalui tatap muka namun beralih pada dunia digital yang proses promosinya lebih luas tidak hanya bertujuan kepada satu orang saja.

Pengabdian ini akhirnya menemukan solusi yang tepat bagi pelaku bisni bahwa hadirnya e-bussines memberi dampak yang signifikan bagi keberlangsungan proses jual beli barang pada pelaku usaha di desa dapenda. Kami juga memberikan pemahaman bagaimana cara memprmosikan barang menjadi bernilai sehingga menambah peminat tertarik untuk membeli usaha yang dikelola oleh pelaku usaha di Dapenda.

Tim pengabdian Universitas wiraraja mempersilahkan kepada para pelaku usaha atau dagang untuk aktif bertanya tentang kendala kendala yang dihadapinya, mulai dari memilih gambar promosi barang untuk dinaikkan ke marketplace, penentuan harga, dan negoisasi dengan calon pembeli. Sehingga pengabdian ini benar benar menjadi solusi bagi warga di desa dapenda dalam rangka membantu mengembangkan usaha dan mendapatkan hasil lebih secara ketahanan perekonomiam warga pelaku usaha dan dagang di Desa Dapenda.

Melalui e-business ini penjual tidak lagi perlu bertemu dengan pembeli cukup dengan melakukan promosi melalui 
mampu memberikan dampak positif bagi pendapatan masayarakat pedagang Desa Dapenda Kecamatan Batang-batang Kabupaten Sumenep.

\section{Ucapan Terima Kasih}

Ucapan terimaksih saya kepada Universitas Wiraraja yang telah mendukung kegiatan pengabdian ini hingga selesai.

\section{DaftarPustaka}

Adi Setiawan dkk. Penerapan Modifikasi Technology Acceptance Model (TAM) Dalam e-Businerss.Jurnal Manajemen dan Pemasaran Jasa Vol. 10 No. 2 September 2017. ISSN : 2442 - 9732 (Online) ISSN : 0216 - 3780 (Print).

Ilham Thaief. Aspek Kesiapan Sumber Daya Manusia Dalam Pembangunan EBusiness Indonesia. Fakultas Ekonomi Universitas Negeri Makassar. Jurnal Economix Volume 2 Nomor 1 Juni 2014.

Yanuar Nurdiansyah. Perancangan Sistem E-Commerce pada industry Terasi Menggunakan Metode Structure Analysis And Design Tecnique (SADT) Guna Meningkatkan Pemasaran Produk (Studi Kasus : Industri Terasi Payangan). Universitas Jember Tahun Anggaran 2017. 